\title{
EFEKTIVITAS MODEL PEMBELAJARAN LITERASI KRITIS BERBASIS PENDEKATAN KONSEP UNTUK MENINGKATKAN KETERAMPILAN MENULIS KREATIF SISWA SEKOLAH DASAR
}

\author{
Mimin Ninawati \\ Universitas Muhammadiyah Prof. Dr Hamka \\ miminninawati30@gmail.com
}

\begin{abstract}
The purpose of this study is to analyze whether conference writing-based literacy learning is able to improve creative writing skills in elementary school students and to analyze whether there are differences in creative writing skills between students who are given literacy learning based on conference writing methods and those not given literacy based learning conference writing method. The research method used is a quantitative research model with an experimental method. The research design used in this study was Quasi Experimental Design with the form of Nonequivalent Control Group Design. In the design of this study researchers used one experimental group with a control group that began with the pretest in each group. The experimental group was given treatment while the control group was not given treatment. At the end of the study posttest will be given to the two groups. In the normality test it is stated that the data is not normal so it is tested with the Wilcoxon formula. Based on the hypothesis analysis test it can be concluded that there are differences in creative writing skills in students before and after using the critical literacy learning model based on the concept approach.
\end{abstract}

Key Words: Creative Writing Skills, Critical Literacy, Concept Approach

\begin{abstract}
ABSTRAK
Tujuan dari penelitian ini adalah Untuk menganalisis apakah pembelajaran literasi berbasis metode conference writing mampu meningkatkan keterampilan menulis kreatif pada siswa sekolah dasar dan Untuk menganalisis apakah terdapat perbedaan keterampilan menulis kreatif antara peserta didik yang diberi pembelajaran literasi berbasis metode conference writing dan yang tidak diberi pembelajaran literasi berbasis metode conference writing. Metode penelitian yang digunakan adalah model penelitian kuantitatif dengan metode eksperimen. Desain penelitian yang digunakan dalam penelitian ini adalah Quasi Experimental Design dengan bentuk Nonequivalent Control Group Design. Pada rancangan penelitian ini peneliti menggunakan satu kelompok eksperimen dengan kelompok kontrol yang diawali dengan pemberian pretest pada masing-masing kelompok. Kelompok eksperimen diberikan perlakuan sedangkan kelompok kontrol tidak diberikan perlakuan. Pada akhir penelitian akan diberikan posttest kepada kedua kelompok tersebut. Pada uji normalitas dinyatakan bahwa data tidak normal sehingga diuji dengan formula Wilcoxon. Berdasarkan uji analisis hipotesis dapat disimpulkan bahwa ada perbedaan keterampilan menulis kreatif pada siswa sebelum dan
\end{abstract}


sesudah menggunakan model pembelajaran literasi kritis berbasis pendekatan konsep.

Kata Kunci: Keterampilan Menulis Kreatif, Literasi Kritis, Pendekatan Konsep

\section{A. Pendahuluan}

Literasi Indonesia masih jauh tertinggal dibandingkan dengan negara-negara lain di seluruh dunia. Pada tahun 2011, data dari International Results in Reading (PIRLS) menunjukkan bahwa Indonesia menduduki posisi 45 dari 48 negara yang menjadi peserta (Faizah dkk. 2016). Pada tahun 2012, data Programme for International Student Assesment (PISA) menunjukkan bahwa Indonesia menduduki peringkat 64 dari 65 negara yang diteliti (OECD, 2013). Sedangkan pada tahun 2016, studi World Most Literate Countries yang dilakukan oleh Presiden Central Connecticut State University (CCSU) menunjukkan bahwa Indonesia berada di peringkat 60 dari 61 negara (Arungbudoyo, 2018).

Rendahnya literasi membuat berbagai usaha peningkatan literasi semakin gencar digaungkan. Salah satu usaha untuk meningkatkan kemampuan literasi peserta didik dilakukan dengan mengembangkan gerakan literasi sekolah (GLS).
Literasi sekolah adalah kemampuan mengakses, memahami, dan menggunakan sesuatu secara cerdas melalui berbagai aktivitas, seperti membaca, melihat, menyimak, menulis, dan/atau berbicara (Faizah dkk. 2016). Setidaknya ada empat keterampilan yang harus dikuasai oleh peserta didik yaitu menyimak, membaca, berbicara dan menulis. Keempatnya saling berhubungan dan memiliki perannya masing-masing.

Salah satu keterampilan literasi yang memerlukan proses pembelajaran panjang adalah menulis. Berdasarkan jenisnya, kegiatan menulis dapat dikelompokkan menjadi dua yaitu menulis akademis dan menulis kreatif (Gerard, 1996). Keterampilan menulis secara garis besar juga dapat dikelompokkan menjadi dua, yaitu menulis permulaan dan menulis tingkat lanjut. Keterampilan menulis permulaan adalah kegiatan menulis dengan menjiplak, menebalkan, mencontoh, melengkapi, menyalin, dan dikte. Literasi diharapkan mampu meningkatkan keterampilan menulis 
tingkat lanjut dimana peserta didik mampu mengungkapkan pikiran, perasaan, dan informasi dalam bentuk percakapan, petunjuk, dan cerita. Salah satu keterampilan menulis tingkat lanjut adalah menulis kreatif. Greene dan Petty (1991) menjelaskan bahwa menulis kreatif merupakan suatu kegiatan mengarang yang sifatnya personal dan tidak selamanya mempunyai kegiatan praktis. Menulis kreatif dapat juga diartikan sebagai kemampuan untuk mengendalikan pikiran kreatif yang ada dalam pikiran dan menuangkannya dalam sebuah kalimat dengan struktur yang baik. Salah satu bentuk kegiatan menulis kreatif adalah mengarang. Karangan dapat dianggap sebagai hasil menulis kreatif apabila memenuhi beberapa kriteria seperti asli, spontan, dan imaginatif.

Selain mengembangkan kemapuan literasi siswa, menulis kreatif merupakan kegiatan positif yang sangat penting serta memiliki manfaat bagi kehidupan siswa kedepannya. Menulis kreatif terbukti mampu mempertahankan kesehatan mental bagi penulisnya. Seseorang yang terbiasa menulis memiliki kesehatan mental yang lebih baik dibandingkan dengan mereka yang tidak terbiasa menulis. Hal ini didukung oleh penelitian Lowe (2006) yang mengatakan bahwa semakin sering seseorang menulis, maka semakin sehat pula mental orang tersebut. Hal ini dapat terjadi karena dengan menulis beban psikologis yang dialami seseorang dapat terekspresikan melalui tulisannya.

Pentingnya kemampuan menulis kreatif pada siswa ternyata tidak didukung oleh praktik pendidikan yang ada pada saat ini. Praktik pendidikan yang ada di kelas cenderung bersifat konvensional atau tidak menarik bagi siswa, guru jarang memberikan kesempatan pada siswa untuk praktik mengarang, dan minat membaca rendah yang berdampak pada kurangnya wawasan serta perbendaharaan siswa sehingga sulit untuk menuangkan ide mereka ke dalam bentuk tulisan (Kumara, 2008). Untuk meningkatkan kemampuan menulis kreatif siswa diperlukan metode pengajaran yang tepat.

Keterampilan menulis kreatif dapat dicapai peserta didik apabila peserta didik melakukan latihan secara intens. Selain itu perlu adanya kerjasama antara peserta didik dan guru agar tujuan tersebut tercapai. Penelitian terdahulu menunjukkan 
Pendas : Jurnal IImiah Pendidikan Dasar, ISSN Cetak : 2477-2143 ISSN Online : 2548-6950

Volume IV Nomor 1, Juni 2019

pembelajaran yang lebih menekankan kerja kolaborasi lebih memiliki keunggulan apabila dibandingkan dengan menulis sendiri (Tinarni, 2010). Metode menulis bersama antara peserta didik dan guru disebut conference writing. Metode conference writing ini masih jarang diterapkan di pendidikan sekolah dasar, karena itu peneliti tertarik untuk menganalisis apakah metode ini benar-benar efektif untuk meningkatkan kemampuan menulis kreatif bagi peserta didik di sekolah dasar.

\section{B. Metode Penelitian}

Metode penelitian yang digunakan adalah model penelitian kuantitatif dengan metode eksperimen. Metode eksperimen adalah metode penelitian yang digunakan untuk mencari pengaruh perlakuan tertentu terhadap yang lain dalam kondisi yang terkendalikan (Sugiyono, 2014:107).

Desain penelitian yang digunakan dalam penelitian ini adalah Quasi Experimental Design dengan bentuk Nonequivalent Control Group Design. Pada rancangan penelitian ini peneliti menggunakan satu kelompok eksperimen dengan kelompok kontrol yang diawali dengan pemberian pretest pada masing-masing kelompok. Kelompok eksperimen diberikan perlakuan sedangkan kelompok kontrol tidak diberikan perlakuan. Pada akhir penelitian akan diberikan posttest kepada kedua kelompok tersebut. Rancangan Penelitian ditunjukkan pada Gambar 3.2 berikut.

\section{$\mathrm{O}_{1} \quad \mathrm{X} \quad \mathrm{O}_{2}$}

\section{Gambar 3.2. Rancangan Penelitian}

Populasi dalam penelitian ini adalah seluruh siswa/siswi kelas IV SDN Cipayung 03 Pagi. Populasi penelitian ini berjumlah 30 siswa yang terdiri dari satu kelas yaitu kelas. Pengambilan sampel dilakukan dengan teknik sampel jenuh, dimana semua anggota populasi dipilih sebagai anggota sampel. Sampel yang diambil pada penelitian ini sebanyak 30 siswa.

Teknik pengumpulan data pada penelitian ini menggunakan observasi dan tes. Sedangkan teknik analisis dalam penelitian ini menggunaka uji komparasi dengan paired sample t-test. Paired Sample Ttest digunakan untuk menguji nilai pretest dan posttest pada satu 
kelompok yang sama. Analisis data ini dilakukan dengan menggunakan bantuan Program SPSS 25.0

\section{Hasil Penelitian dan Pembahasan}

Ada beberapa tahapan uji coba dalam penelitian ini yaitu uji validitas dan reliabilitas. Pada uji validitas, Aitem-aitem pada angket diuji validitasnya dengan korelasi aitem total untuk mendapatkan aitem yang valid. Berdasarkan uji validitas aitem dengan korelasi aitem total, beberapa aitem dinyatakan gugur. Aitem dengan nilai $r$ hitung $<r$ tabel $(0,334)$ dinyatakan tidak valid, sementara aitem dengan nilai $r$ hitung $>r$ tabel dinyatakan valid. Berdasarkan pertimbangan tersebut maka ada lima aitem yang gugur, yaitu aitem no. 1, 3, 5, 15, dan 16.

Setelah mendapatkan aitemaitem yang valid, selanjutnya dilakukan uji reliabilitas. Uji reliabilitas dilakukan untuk mendapatkan alat ukur yang memiliki konsistensi tinggi dalam mengukur aktivitas siswa ketika melakukan aktivitas menulis. Berdasarkan uji reliabilitas dengan formula alpha cronbach diperoleh nilai koefisien reliabilitas sebesar 0,859 . Hal ini menunjukkan bahwa angket ini sangat reliabel dalam mengukur aktivitas siswa dalam menulis kritis.

Tabel 1 Uji Reliabilitas
Reliability Statistics

Cronbach's Alpha N of Items

.859 15
Pada uji hipotesis ini ada beberapa tahapan uji coba yang dilakukan oleh peneliti yaitu uji noramalitas dan uji analisis. Pada Uji normalitas merupakan prasyarat dilakukan uji paired sample t-test. Uji normalitas dilakukan untuk mengetahui apakah data berdistribusi normal atau tidak. Data dikatakan berdistribusi normal apabila memiliki nilai signifikansi > 0.05, sedangkan data dengan signifikansi $<0.05$ dinyatakan tidak berdistribusi normal. Berdasarkan uji normalitas dengan formula shapiro wilk pada hasil pretest diperoleh nilai signifikansi sebesar 0.092 (> 0.05), maka data dinyatakan berdistribusi normal. Sedangkan pada hasil post test diperoleh nilai signifikansi sebesar 0.003 (< 0.05), maka data dinyatakan tidak berdistribusi normal. Berdasarkan hasil tersebut diketahui bahwa analisis hipotesis dengan menggunakan uji paired sample $t$ test tidak dapat 
Pendas : Jurnal IImiah Pendidikan Dasar, ISSN Cetak : 2477-2143 ISSN Online : 2548-6950

Volume IV Nomor 1, Juni 2019

dilakukan karena hanya satu kelompok data yang berdistribusi normal. Oleh karena itu, analisis hipotesis selanjutnya dilakukan dengan menggunakan uji non parametrik dengan formula wilcoxon.

Tabel 2 Uji Normalitas

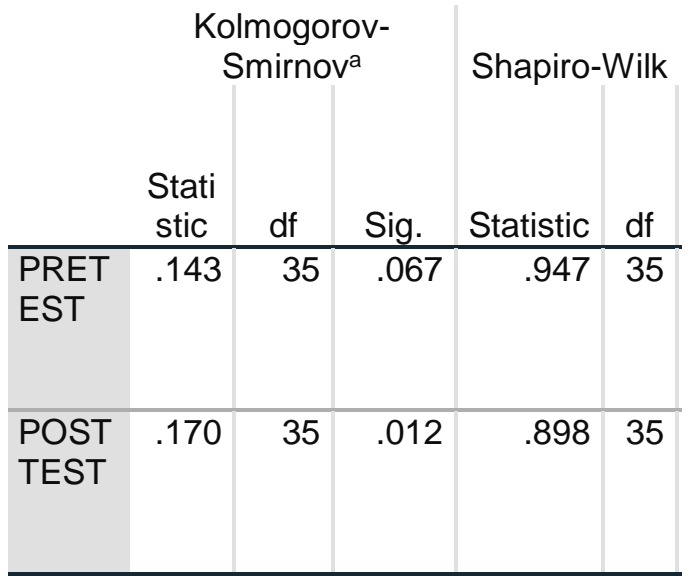

a. Lilliefors Significance Correction

Uji analisis dengan formula wilcoxon dipilih karena data tidak berdistribusi normal. Berdasarkan hasil uji beda dengan formula wilcoxon, diperoleh nilai signifikansi sebesar $0.000 \quad(<0.05)$ sehingga dinyatakan bahwa ada perbedaan keterampilan menulis kreatif pada siswa sebelum dan sesudah menggunakan model pembelajaran.

Tabel 3 Tabel Uji Analisis Test Statistics ${ }^{a}$

POSTTEST - PRETEST

Z $-5.162^{b}$

Asymp. Sig. (2-tailed) $\quad .000$

a. Wilcoxon Signed Ranks Test

b. Based on negative ranks.
Literasi

mengandung

pemaknaan melek terhadap pembaharuan di sekitar. Literasi pada abad 21 telah masuk ke dalam sendisendi kehidupan salah satunya dalam dunia pendidikan. Pendidikan literasi kritis membantu siswa mengeksplorasi hubungan bahasa dan kekuatan dan berfokus pada kebutuhan untuk menciptakan pembicara, pembaca, dan penulis kritis yang dapat mendekonstruksi teks-teks yang mengelilinginya dan menafsirkannya, baik sebagai produk dan proses praktik sosial tertentu. Dalam konteks ini, literasi diakui sebagai sumber pembuatan makna yang didefinisikan secara ideologis (loannidou, 2015). Sedangkan menurut Cooper \& White (2008) menyatakan bahwa Literasi Kritis berkaitan denga proses mengembangkan kapasitas diri (efikasi diri) untuk membaca dibarengi dengan sebuah sikap pencarian, dan keinginan untuk mempengaruhi perubahan sosial yang positif. Senada dengan pendapat Lee (2016) yang mendefinisikan literasi kritis sebagai belajar membaca dan menulis sebagai bagian dari proses menjadi sadar akan pengalaman seseorang yang dibangun secara historis dalam 
Pendas : Jurnal IImiah Pendidikan Dasar, ISSN Cetak : 2477-2143 ISSN Online : 2548-6950

Volume IV Nomor 1, Juni 2019

hubungan kekuasaan yang spesifik.

Oleh karena itu, tujuan literasi kritis adalah untuk menantang hubungan kekuatan yang tidak setara ini. Sehingga kesimpulannya bahwa literasi kritis adalah kemampuan seseorang untuk mengembangkan kemampuan literasi baik itu membaca atau menulis guna menemukan kesenjangan sosial yang merepresentasikan penyalahgunaan kekuasaan, penindasan, marjinalisasi, dan segala bentuk kritis kemanusiaan, proses ini tidak hanya melibatkan kemampuan kognitif, tapi lebih dalam lagi melibatkan kesadaran dan pengalaman. Tak sebatas itu, literasi kritis juga dapat mengembangkan hasrat emansipatif untuk senantiasa menginginkan perubahan yang positif pada situasi sosio-cultural manusia. Pada perubahan positif tersebut dibutuhkan suatu pendekatan di dalam pembelajaran yang dilakukan oleh guru.

Pendekatan konsep merupakan salah satu pendekatan yang sering digunakan oleh para guru. Melalui pendekatan konsep, guru membimbing dan mengarahkan siswa untuk memahami suatu topik dengan cara memahami konsep-konsep yang terkandung dalam topik tersebut.
Semua kegiatan yang dilakukan dalam kegiatan pembelajaran diarahkan pada penguasaan konsep dan sub konsep dalam topik tersebut (widodo: 2017). Setelah siswa memahami suatu konsep dalam topik tertentu, siswa mampu mengembangkan ide dan pengalaman belajar dalam suatu wadah, salah satunya yaitu dengan menulis.

Menulis merupakan salah satu keterampilan dalam berbahasa. Gie (2002) mengungkapkan bahwa menulis adalah rangkaian kegiatan seseorang mengungkapkan buah pikirannya melalui bahasa tulis untuk dibaca atau dimengerti oleh orang lain. Buah pikiran itu dapat berupa pengalaman, pendapat, pengetahuan, perasaan dampak gejolak kalbu seseorang. Menulis bertujuan mengungkapkan fakta-fakta, perasaan, sikap, dan isi pikiran secara jelas dan efektif kepada pembaca. Sedangkan Suparno (2007) menyatakan bahwa dengan menulis kita dapat meningkatkan kecerdasan, mengembangkan daya inisiatif dan kreativitas, menumbuhkan keberanian dan mendorong kemauan, serta kemampuan untuk mengumpulkan informasi. Salah satu jenis 
Pendas : Jurnal IImiah Pendidikan Dasar, ISSN Cetak : 2477-2143 ISSN Online : 2548-6950

Volume IV Nomor 1, Juni 2019

keterampilan menulis yaitu keterampilan menulis kreatif.

Menulis kreatif merupakan bagian dari hasil atau produk kreativitas yang dalam prosesnya melibatkan unsur keterampilan.

Dalam pelaksanaannya menulis kreatif membutuhkan bimbingan dan prosesnya yang berkesinambungan. Jika bimbingan penulisan kreatif disekolah dikembangkan maka akan memberikan sumbangan terhadap pemekaran dan pengayaan khasanah sastra Indonesia. Bagi siswa bimbingan penulisan kreatif dapat meningkatkan daya kreasi para siswa selain itu membantu mengembangkan daya imajinasi, meluaskan fantasi, dan mengayakan memori. Sasaran utamanya bukan hanya pada logika tapi rasa senang dan estetika. Pranoto (2012) menjelaskan bahwa dalam menulis kreatif Pembaca terkagum bukan karena kebenaran, logika, dan fakta, melainkan pada kebenaran artistik yang ukurannya adalah kepekaan intuitif. Manfaat mengembangkan keterampilan menulis kreatif anak salah satunya untuk memiliki otak kanan dan kiri yang seimbang. Hal ini selaras dengan pendapat Olivia (2012) bahwa untuk merangsang anak belajar menulis,sistem pembelajaran alamiah otak sangat efektif, bahkan hampir seluruh potensi dimiliki oleh seorang pembelajar akan tergarap dan terbangkitkan. Pengalaman yang diterima dan disimpan diotak belakang dapat diungkapkan dengan kata-kata sendiri dan hal inipun akan berperan dalam pengembangan kreativitas siswa untuk mengolah kata. Selain hal tersebut diatas Olivia (2012) menjelaskan bahwa kegiatan menulis kreatif memungkinkan sistem pembelajaran alamiah otak dapat terjadi. Terlebih keterampilan membaca dan menulis berkembang bersama dan saling mempengaruhi. Menulis membantu mengembangkan keterampilan memperhatikan (konsentrasi), memahami (arti), dan membedakan (menghubungkan sandi dengan asosiasi dan perasaan). Berdasarkan pada pendapat tersebut dapat disimpulkan bahwa ketika seseorang belajar menulis maka ketika itu pula seseorang itu melakukan aktifitas membaca karena keduanya ini berkembang secara bersamaan dan terintegrasi yang kemudian saling member pengaruh. 
Pendas : Jurnal IImiah Pendidikan Dasar, ISSN Cetak : 2477-2143 ISSN Online : 2548-6950

Volume IV Nomor 1, Juni 2019

Keterampilan menulis harus sejalan dengan keterampilan membaca dan dalam menulis kreatif hal ini menjadi bagian penting yang diperhatikan dalam pembelajaran menulis kreatif. Brown (dalam Kurniawan, 2013) menjelaskan bahwa "perlu jadi kesadaran bersama bahwa pembelajaran sebenarnya adalah penciptaan kondisi agar siswa belajar dengan aktif dan kreatif". Selaras dengan hal tersebut Kurniawan (2013) menjelaskan bahwa, "substansi pembelajaran adalah belajar sehingga pembelajaran merupakan proses aktivitas yang dilakukan guru dalam mengkondisikan siswa untuk belajar. Artinya belajar untuk mengetahui, memahami, menerapkan, menganalisis, menyintesis, dan mengevaluasi materi yang menjadi bahan pembelajaran"

Kegiatan menulis kreatif dapat terjadi dengan berbasis komunikatif dan apresiatif. Kurniawan (2013) menjelaskan bahwa, "pembelajaran menulis berbasis komunikatif berorientasikan pada pembelajaran yang melibatan interaksi komunikatif guru dengan siswa sebagai usaha untuk mengeksplorasi gagasan siswa sebagai bahan tulisan dan penjelasann guru sebagai cara untuk memberi trik menuliskan ide gagasan itu dengan mudah". Berdasarkan pendapat tersebut maka dalam mengeksplorasi ide-ide siswa komunikasi antara guru dan siswa dalam menulis kreatif berperan penting. Sehingga pada pelaksanaannya guru tidak akan membiarkan siswa tanpa arahan untuk menulis. Selain Berbasis komunikatif pada pelaksanaanya penulisan dengan creative writing adalah berbasis apresiatif. Kurniawan (2013) menjelaskan bahwa pembelajaran yang berbasis apresiasif berarti pembelajaran yang berbasis penghargaan, yaitu penghargaan terhadap anak-anak sebagai siswa. Penghargaan ini berwujud pada penghargaan terhadap anak-anak dengan segala ciri khas perkembangan dan penghargaan terhadap hasil tulisannya. Melalui proses pembelajaran tersebut dengan berbasis komunikatif yang menyenangkan dan mengembangkan ide-ide yang ada dalam diri siswa dengan memperhatikan dunia siswa yang berada pada tahap dunia bermain dan memiliki daya imajinasi tinggi maka pembelajaran akan 
Pendas : Jurnal IImiah Pendidikan Dasar, ISSN Cetak : 2477-2143 ISSN Online : 2548-6950

Volume IV Nomor 1, Juni 2019

mampu membantu siswa untuk menulis dengan kreatif. Pada pembelajaran berbasis apresiasif guru akan mengembangkan aspek menyimak-berbicara dan menulismembaca terhadap karya siswa dan dapat disimpulkan bahwa pembelajaran penekanannya pada kegiatan belajar siswa yang telah dirancang oleh guru melalui usaha yang terencana dalam mengkondisikan siswa untuk aktif kreatif dalam belajar sehingga akan menghasilkan perubahan perilaku secara komprehensif.

\section{Kesimpulan}

Model pembelajaran literasi kritis melalui pendekatan konsep mampu meningkatkan keterampilan menulis kreatif di sekolah dasar. Berdasarkan hasil uji hipotesis penelitian didapatkan bahwa terdapat perbedaan yang signifikan sebelum dan sesudah menggunakan model pembelajaran literasi kritis di sekolah dasar. Siswa sekolah dasar yang menggunakan model pembelajaran literasi kritis berbasis pendekatan konsep mempunyai keteampilan menulis kreatif meningkat, hal tersebut dilihat dari hasil observasi pada saat proses pembelajaran dan soal tes pada akhir pelaksanaan pembelajaran.

\section{ACKNOWLEDGE}

Ucapan terima kasih peneliti sampaikan kepada Lemlitbang Uhamka yang telah memberikan dana penelitian sehingga penelitian dapat berjalan dengan baik. Rektor, Dekan FKIP, kaprodi PGSD Uhamka, dan seluruh dosen PGSD yang selalu memberikan motivasi dan dorongan untuk aktif menghasilkan publikasi ilmiah.

\section{DAFTAR PUSTAKA}

Arungbudoyo, W. (2018). Paling Rendah Se-Asia Tenggara, Peringkat Berapa Minat Baca Masyarakat Indonesia?. (online), https://lifestyle.okezone.com, diakses pada 26 Desember 2018.

Faizah, D. U., Susanti, S., Lanny, A., Waluyo, Sofie, D., Wien, M., \& Dwi, R. R. (2016). Panduan Gerakan Literasi Sekolah di Sekolah Dasar. Jakarta: Direktorat Pembinaan Sekolah Dasar, Direktorat Jenderal Pendidikan Dasar dan Menengah Kementerian Pendidikan dan Kebudayaan.

Gerrard, P. (1996). Creative nonfiction: Researching and Crafting Stories From Real Life. Cincinnati: Story Press.

Gie, The Liang. 2002. Terampil Mengarang. Yogyakarta. ANDI. 
Pendas : Jurnal IImiah Pendidikan Dasar, ISSN Cetak : 2477-2143 ISSN Online : 2548-6950

Volume IV Nomor 1, Juni 2019

Graves, D. H. (1983). Writing: Teachers and Children at Work. Portsmouth: Heinemann.

Hendriani, A, Nuryani, P, Ibrahim T. (2017). Desain Pendidikan Hadap Masalah Berbasis Literasi Kritis di Sekolah Dasar. Laporan Penelitian Afirmasi LPPM UPI.

Hartati, T. (2009). Penerapan Pendekatan Conferencing dalam Pembelajaran Menulis di Sekolah Dasar. Jurnal Pendidikan Dasar, Vol. 11, 45-53.

loannidou, E. (2015). Critical literacy in the first year of primary school: Some insights from Greek Cypriot classrooms. Journal of Early Childhood Literacy, 15(2), 177202

Kasmidawati. (2018). Application of Conference Writing Methods Can Improve Short Story Writing Skills. Jurnal IImiah Pendidikan Scholastic, Vol. 1 No. 2.

Kumara, A. (2008). Dampak Kemampuan Verbal Terhadap Kualitas Ekspresi Tulis. Psikoislamika, Vol. 5 No. 1, 83-91.

Lowe, G. (2006). Health-Related Effects of Creative and Expressive Writing. Health Education, Vol. 106 No. 1, 60-70.

OECD. (2014). PISA 2012 Results in Focus: What 15-year-olds Know and What They Can Do With What They Know.

Setiawati, I. (2016). Strategi Meningkatkan Kemampuan Menulis Karangan Kreatif Pada Siswa Kelas 4 dan 5. Dinamika Penelitian, Vol. 16 No. 1.

Sidiq, S., Wahyudi, B. P., dan Anindita, D. (2013). Pelatihan
Menulis Kreatif untuk Mengembangkan Potensi Kreativitas Anak. Seri Pengabdian Masyarakat 2013, Vol.2 No. 3, 217-223.

Sukmawan, S. (2013). Mencipta Kreatif Naskah Drama dengan Strategi Menulis Terbimbing. Sirok Bastra Jurnal IImiah Kebahasaan dan Kesastraan, Vol. 1 No. 2, 195-205.

Suparno, Paul. (2007). Pendidikan Multikultural. Kompas Cyber Media (KCM).

Tarigan \& Guntur, H. (2008). Menulis Sebagai Suatu Keterampilan Berbahasa. Bandung: Angkasa.

Teguh, M. (2017). Gerakan Literasi Sekolah Dasar. Prosiding Seminar Nasional 15 Maret 2017.

Tinarni. (2010). Meningkatkan Keterampilan Menulis Karangan Dengan Topik Lingkungan Melalui Conference Writing Pada Siswa Kelas IV SDN Krondonan III Gondang Bojonegoro. Skripsi. Fakultas Keguruan dan IImu Pendidikan UMM.

Tryanasari, D. (2012). Menumbuhkan Karakter Baik (Good Character) Melalui Menulis Kreatif di Sekolah Dasar. (online), htpps://publikasiilmuah.ums.ac.id. Yarmi, G. (2014). Meningkatkan

Kemampuan Menulis Kreatif

Siswa Melalui Pendekatan Whole Language dengan Teknik Menulis Jurnal. Perspektif IImu

Pendidikan, Vol. 28 No. 1, 8-16. 